\title{
Monooxygenase enzyme activity in alcoholics with varying degrees of liver damage ${ }^{1}$
}

\author{
H. HOENSCH ${ }^{2}$, F. HARTMANN, H. SCHOMERUS, P. BIECK, AND W. DÖLlE \\ From the Department of Medicine, Gastroenterology Section, University of Tübingen, \\ Federal Republic of Germany
}

SUMMARY Monooxygenase enzymes are involved in the biotransformation of drugs and of environmental carcinogens. The activity of 7-ethoxycoumarin 0-deethylase and associated NADPHcytochrome c reductase was determined in $9000 \mathrm{~g}$ supernatant from bioptically obtained liver specimens from patients with various liver diseases in order to study in vitro drug metabolising capacity. Monooxygenase and reductase activity was significantly higher in the livers of 21 patients with alcoholic liver disease (fatty liver, alcoholic hepatitis, cirrhosis of the liver) than in 22 normal controls or in six patients with chronic active hepatitis. The raised activity of drug-metabolising enzymes obtained from alcoholics with liver damage differs from normal values found in five alcoholics without liver disease. Both groups were comparable in respect to the amount of alcohol consumed and duration of abuse. A strikingly low monooxygenase activity was observed in eight patients with cirrhosis of the liver and ascites, with, however, no apparent effect on reductase activity. The results show that alcoholic liver disease is associated with enhanced monooxygenase and reductase activity, but alcoholism, per se, is not. This rise of drug-metabolising enzyme activity could lead to selectively increased rates of biotransformation in patients with alcoholic liver damage.

It has been shown that there is an increased rate of drug-metabolism in alcoholics when they are abstinent (Misra et al., 1971). These studies have not reported, however, whether differences exist between alcoholics with liver damage and those without (Kater et al., 1969; Misra et al., 1971; Neuvonen et al., 1976). Furthermore, data were mostly obtained from in vivo experiments and in vitro data from studies with humans is scarce (Schoene et al., 1972; Shah et al., 1972; Krat $z$, 1976). The kinetics of drug metabolism are largely dependent on the activity of drug-metabolising enzymes in the liver, although a large variety of factors, such as volume of distribution, protein binding, and hepatic circulation may influence kinetic rates.

Drug-metabolising enzymes are located in the smooth endoplasmic reticulum of the liver cells,

\footnotetext{
${ }^{1}$ Presented in part at the Annual Meeting of the European Association for the study of the Liver in Athens, Greece, September 1977.

Supported by a grant from the Deutsche Forschungsgemeinschaft.

${ }^{2}$ Address for correspondence: Dr Harald Hoensch, Department of Gastroenterology, University of Tübingen, D-7400 Tübingen 1, Federal Republic of Germany.

Received for publication 21 February 1979.
}

although enzyme activity occurs in other organs, such as the small intestine, the lungs, and the skin (Hoensch et al., 1976). These microsomal enzymes participate in the biotransformation of a large variety of foreign substances such as drugs, environmental carcinogens, and other lipophilic compounds (Remmer, 1970). Monooxygenase enzymes play a major role among these enzymes, being able to catalyse the reaction:

$$
\begin{array}{r}
\mathrm{R}-\mathrm{CH}_{3}+\mathrm{O}_{2}+\mathrm{NADPH}+\mathrm{H}^{+} \leftrightharpoons \\
\mathrm{R}-\mathrm{CH}_{2} \mathrm{OH}+\mathrm{NADP}++\mathrm{H}_{2} \mathrm{O} .
\end{array}
$$

This process leads to more polar products, which are more water-soluble. This constitutes in many instances a detoxification reaction, which could protect the organism from the harmful effects of lipophilic toxicants (Wattenberg, 1972). Nevertheless, some of the products of monooxygenase reactions might be more toxic than the parent compounds and various other factors such as half-life, binding capacity, and chemical stability, as well as additional metabolism of the active intermediate, determine what the final effect of the biotransformation will be.

It has been suggested that microsomal monooxygenases are also involved in ethanol metabolism (Lieber and DeCarli, 1970). As there are marked 
variations in individual susceptibility not only to the toxic side-effects of drugs, but to alcohol as well, it seemed important to examine the in vitro monooxygenase activity in the liver of individual patients.

We measured the enzymatic activity of one monooxygenase enzyme, 7-ethoxycoumarin 0-deethylase (EOD) and the activity of the associated electrondonating enzyme-NADPH-cytochrome $c$ reductase -in biopsy specimens from patients with liver damage due to alcohol as well as to other causes and in patients with no liver disease.

\section{Methods}

Liver biopsy specimens were taken during peritoneoscopy from 81 patients (54 male and 27 female). This procedure was done within the first 20 days after admission to the hospital in order to assess the extent of liver damage. Ten to twenty milligrams of wet weight were used for enzyme determination; the remainder for histological examination. None of the alcohol-abusing patients had been abstinent at the time of admission. The patients were carefully questioned about their previous drug therapy and their smoking habits.

The mean interval between admission and biopsy was $7 \cdot 2 \pm 4 \cdot 7$ days in all cases: for the alcoholics with liver damage (group II) it was $\mathbf{7 \cdot 8} \pm \mathbf{4 \cdot 2}$ days and for

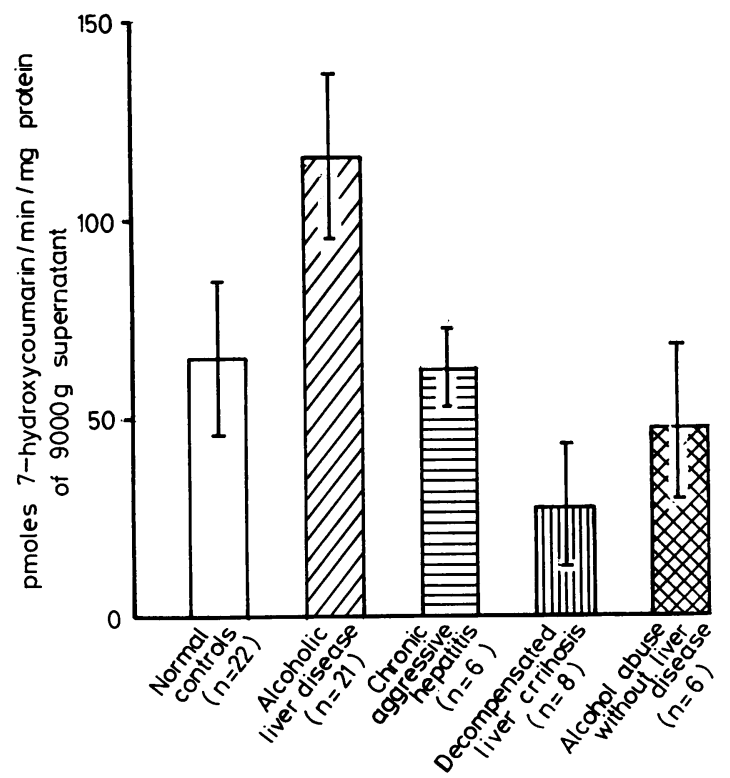

Fig. 1 Activity of 7-ethoxycoumarin 0-deethylase in $9000 \mathrm{~g}$ supernatant of human liver biopsy specimens from patients with and without liver disease. Mean \pm standard deviation of individual values are indicated. the alcoholics without liver disease (group V) $12 \cdot 2 \pm$ $7 \cdot 2$ days. The amount of ethanol consumed per day for at least five years was reportedly $142 \pm 52 \mathrm{~g}$ in group II and $158 \pm 52 \mathrm{~g}$ in group V. Patients who had been consuming more than $100 \mathrm{~g}$ alcohol per day for at least five years were considered to be alcoholics.

The liver tissue samples were weighed and frozen at $-20^{\circ} \mathrm{C}$ for five to 10 days. Compared with fresh samples the monooxygenase-activity decreased within four days after freezing, though it remained unchanged between the fifth and tenth day in surgical biopsy specimens. After thawing, the sample was homogenised in $0.1 \mathrm{M}$ Tris- $\mathrm{HCl}$ buffer $\left(\mathrm{p}_{\mathrm{H}}=\right.$ 7.6), using a dounce homogeniser, sonicated for 10 seconds at $25 \mathrm{~W}$ and then centrifuged at $9000 \mathrm{~g}$ for 10 minutes. The resulting $1 \%$ supernatant contained $10 \mathrm{mg}$ liver $/ \mathrm{ml}$ and was used for the enzyme assay.

Microsomes were prepared from $9000 \mathrm{~g}$ supernatant with specimens heavier than $20 \mathrm{mg}$ wet weight by centrifuging at $104000 \mathrm{~g}$ for 60 minutes.

EOD activity was determined by the method of Ullrich and Weber (1972), NADPH-cytochrome c reductase with that of Williams and Kamin (1962) and protein concentration with the procedure developed by Lowry et al. (1951).

Appropriate assay conditions for human liver biopsy specimens were established using surgically obtained liver tissue. The $250 \mu 1$ of incubation mixture contained $125 \mu \mathrm{l} 1 \%$ supernatant, $5 \times 10^{-4}$ M 7-ethoxycoumarin, and $2 \times 10^{-4} \mathrm{M}$ NADPH in $0 \cdot 1 \mathrm{M}$ Tris-HCL buffer, $\mathrm{pH} 7 \cdot 6$.

In $9000 \mathrm{~g}$ supernatant the EOD reaction rate was proportional to protein concentrations which ranged from 0.2 to $2.0 \mathrm{mg} / \mathrm{ml}$ and, for the reductase, from concentrations from 0.1 to $3.0 \mathrm{mg} / \mathrm{ml}$. In microsomal suspension both enzyme rates were protein-dependent from 0.1 to $0.6 \mathrm{mg} / \mathrm{ml}$. EOD was linear with time up to 30 minutes, whereas the reductase was linear only up to two minutes. The concentrations of NADPH saturated the enzymes. The KM value of 0-deethylation was $7 \times 10^{-5} \mathrm{M}$ in normal livers. The coefficients of variation of specific EOD activity were $9.13 \%$ in normal livers $(n=7)$ and $17 \cdot 2 \%$ in cirrhotic livers $(n=4)$. Histological evaluation of the biopsy specimens was carried out by an independent pathologist who was unaware of the enzyme values and who classified the liver on a routine basis.

The patients were assigned to the following groups on the basis of clinical and histological criteria:

I NORMAL CONTROLS

( $n=22 ; 15$ male, seven female; age : $46 \cdot 2 \pm 14 \cdot 1$ years) Normal serum liver function tests (SGOT, SGPT, alkaline phosphatase, bilirubin, gamma glutamyltransferase) and normal liver histology were found. 
Peritoneoscopy was performed on all patients who had neoplastic haematological disorders, to rule out liver involvement.

II ALCOHOLIC LIVER DISEASE

( $n=21 ; 18$ male, three female; age : $42 \cdot 5 \pm 12.4$ years)

These patients-all alcoholics-had pathological serum liver function tests, though no signs of liver function decompensation were observed. Histological results showed alcoholic hepatitis in $33 \%$ of the patients $(n=7)$, fatty liver in $53 \%(n=11)$-in addition, two of these patients had Mallory bodiesand alcoholic cirrhosis of the liver in $14 \%(n=3)$. III CHRONIC ACTIVE HEPATITIS

( $n=6$; four male, two female; age : $48 \cdot 8 \pm 19 \cdot 5$ years) Histologically, chronic aggressive hepatitis was described; serum liver enzymes and gamma globulines were raised.

IV CIRRHOSIS OF LIVER WITH CLINICAL DECOMPENSATION

( $n=8$; three male, five female; age : $44 \cdot 3 \pm 11 \cdot 7$ years) Ascites, hypalbuminaemia, and pathological serum liver enzymes were present. The histology showed active cirrhosis of the liver. Six of these eight patients were alcoholics.

V ALCOHOLICS WITHOUT LIVER DAMAGE

( $n \pm 6$; all males; age: $41 \cdot 0 \pm 17 \cdot 6$ years)

Amount and duration of alcohol abuse was similar to that in group II, but these patients showed no functional or histological signs of liver disease.

Bioptically obtained liver tissue was examined which had been taken from five patients who took inducing drugs, six with fatty liver, presumably not caused by alcohol, three with histological signs of chronic pericholangitis, one with hemangioma of the liver, one with intrahepatic cholestasis of unknown aetiology, one with siderosis of the liver, and one with chronic persistent hepatitis.

For statistical analysis the unpaired Student's $t$ test was used to compare group I with group II and the Wilcoxon test to compare groups III, IV, and $\mathrm{V}$ with each other and with groups I and II.

\section{Results}

As shown in Table 1, EOD activity was much higher in patients with alcoholic liver disease than in the other groups. This difference became apparent when the enzyme reaction rate of $1 \% 9000 \mathrm{~g}$ supernatant was expressed in terms of specific activity as well as of total activity per $10 \mathrm{mg}$ of liver wet weight.

The difference of mean values between EOD activity in group I (normal controls) and the activity in group II (alcoholic liver disease) was greater where specific activity was concerned $(P<0.0005)$ than activity per wet weight $(\mathrm{P}<0.0125)$. In group II protein content of $9000 \mathrm{~g}$ supernatant was $0.59 \pm 0.21$
(SD) $\mathrm{mg}$ per $10 \mathrm{mg}$ of wet weight of liver as compared with $0.77 \pm 0.20$ found in normal control subjects.

A similar pattern was found for NADPHcytochrome c reductase: activity was increased in patients with alcoholic liver disease, although the number of cases per group was smaller than for EOD.

Specific EOD activity could be measured in a small number of microsomal preparations: $433.0 \pm$ $97.5 \mathrm{pmol} / \mathrm{min} / \mathrm{mg}$ protein $(\mathrm{n}=3)$ in group II and $268.9 \pm 96.1 \mathrm{pmol} / \mathrm{min} / \mathrm{mg}$ protein $(n=4)$ in group $I$. Although only a few results have been obtained, the difference in microsomal enzyme activity appears to be the same as for the supernatant.

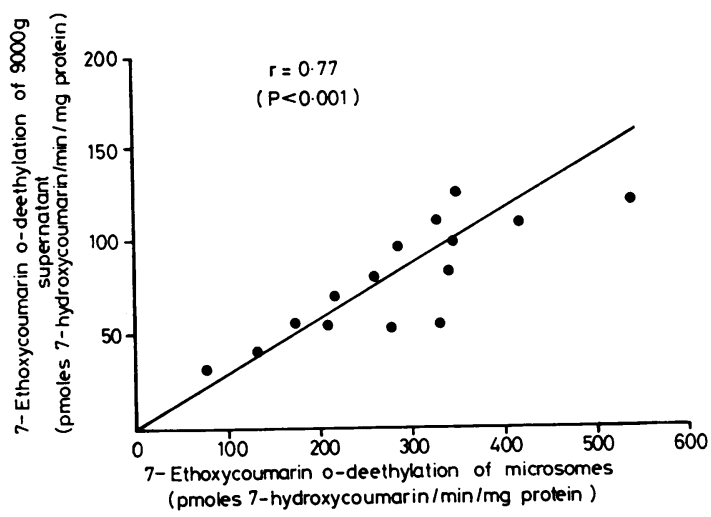

Fig. 2 Relationship between 7-ethoxycoumarin 0 -deethylation of microsomes and $9000 \mathrm{~g}$ supernatant in human liver of patients. Nine thousand grams supernatant and microsomes were prepared from liver biopsy specimens of more than $20 \mathrm{mg}$ of wet weight and enzyme assays were performed in both preparations.

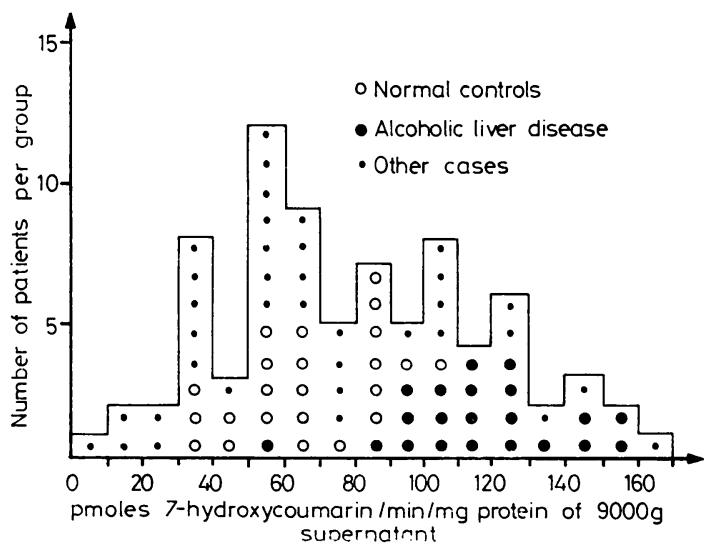

Fig. 3 Frequencies of individual activities of hepatic 4-ethoxycoumarin 0-deethylase in patients with alcoholic liver disease, normal controls, and other cases. 
Table 1 7-ethoxycoumarin 0-deethylation and NADPH-cytochrome c reductase activities in liver biopsy specimens of patients*

\begin{tabular}{|c|c|c|c|c|c|}
\hline \multirow[t]{2}{*}{ Diagnosis } & \multirow[t]{2}{*}{ Group } & \multicolumn{2}{|c|}{$\begin{array}{c}\text { 7-ethoxycoumarin 0-deethylase } \\
\text { (pmol/min) }\end{array}$} & \multicolumn{2}{|c|}{$\begin{array}{c}\text { NADPH-cytochrome } \\
(\text { nmol } / \mathrm{min})\end{array}$} \\
\hline & & per mg protein & per $10 \mathrm{mg}$ wet weight & per mg protein & per $10 \mathrm{mg}$ wet weight \\
\hline $\begin{array}{l}\text { Normal controls } \\
\text { Alcoholic liver disease } \\
\text { Chronic active hepatitis } \\
\text { Decompensated liver cirrhosis } \\
\text { Alcoholics without liver damage }\end{array}$ & $\begin{array}{l}\text { I } \\
\text { II } \\
\text { III } \\
\text { IV } \\
\text { V }\end{array}$ & $\begin{array}{l}65 \cdot 2 \pm 20 \cdot 3(22) \\
116 \cdot 0 \pm 24 \cdot 4(21) \dagger \| \\
62 \cdot 9 \pm 10.0(6) \\
28 \cdot 5 \pm 15 \cdot 6(8) \S \\
49 \cdot 4 \pm 20 \cdot 5(6)\end{array}$ & $\begin{array}{l}50 \cdot 5 \pm 20 \cdot 0(22) \\
68 \cdot 4 \pm 29 \cdot 6(21) \ddagger \| \\
41 \cdot 5 \pm 6 \cdot 8(6) \\
8 \cdot 4 \pm 4 \cdot 7(8) \S \\
37 \cdot 9 \pm 18 \cdot 3(6)\end{array}$ & $\begin{array}{l}33 \cdot 8 \pm 9 \cdot 1(11) \\
58 \cdot 2 \pm 16 \cdot 3(7) \ddagger \| \\
38 \cdot 8(1) \\
35 \cdot 1 \pm 18 \cdot 7(5) \\
33 \cdot 6(2)\end{array}$ & $\begin{array}{l}25 \cdot 0 \pm 7 \cdot 4(11) \\
40 \cdot 1 \pm 11 \cdot 4(7) \ddagger \\
24 \cdot 4(1) \\
14 \cdot 8 \pm 10 \cdot 9(5) \\
17 \cdot 4(2)\end{array}$ \\
\hline
\end{tabular}

*Values represent mean \pm standard deviation of individual determinations in $9000 \mathrm{~g}$ supernatant. Number of cases are given in parenthesis.

†Higher at $P<0.0005$ level than those of group $I$.

$\ddagger$ Higher at $P<0.0125$ level than those of group $I$.

$\$$ Lower at $P<0.01$ level than those of the other groups.

$\|$ Higher at $P<0.01$ than those of the other groups except group [.

Whereas in alcoholic liver disease (group II) both EOD and reductase were raised, a different pattern was observed for patients with decompensated cirrhosis of the liver (group IV). EOD had less than half normal activity in this group, but reductase activity was not affected either by cirrhosis or by liver failure. Alcoholics without liver disease (group V) exhibited EOD and reductase activity that was nearly normal. Although patients with chronic active hepatitis (group III) showed clinical and histological signs of inflammation, no change in monooxygenase activity was found.

Data on drug therapy revealed that, of 19 patients in group II, five were treated with diazepam, one with lorazepam and amitriptyline and another one with phenobarbitone, $20 \mathrm{mg}$ per day; the remainder $(n=12)$ received no tranquillisers or psychoactive drugs. There was no significant difference in specific EOD-activity between the alcoholic patients with and without the drug treatment mentioned $(120 \pm 23$ versus $125 \pm 21 \mathrm{pmol} / \mathrm{min} / \mathrm{mg}$ protein).

Smoking did not affect the monooxygenase activity in these patients either. Similarly, no difference of EOD values was observed among smoking and non-smoking, non-alcoholic patients with normal liver histology $(66 \pm 24, n=4$ versus $63 \pm 27$, $\mathrm{n}=9$ ).

In two patients with non-alcoholic fatty liver and two non-alcoholics with normal liver who were treated with tranquillisers specific EOD activities were not raised $(47 \pm 23)$.

High EOD activity $(128.4 \pm 49.6 \mathrm{pmol} / \mathrm{min} /$ $\mathrm{mg}$ protein) was measured in five patients: two of these patients took phenytoin and carbamazepine, one abused tranquillisers (diazepam, prazepam, chlordiazepoxide) and two female patients had been treated with female sex hormones, one additionally with nitrophenylbenzodiazepine, the other one with medazepam and prazepam. Reductase activity was not measured in these patients. In normal controls a sex difference of EOD activity was not apparent $(\delta=66 \cdot 3 \pm 22 \cdot 6, ?=63 \cdot 4 \pm 15 \cdot 2)$. One patient with siderosis of the liver and another with chronic persistent hepatitis had specific EOD activities of 53.0 and $75.1 \mathrm{pmol} / \mathrm{min} / \mathrm{mg}$ protein.

Frequency of individual EOD values is shown in Fig. 3. As the distribution shows, there is an accumulation of alcoholic liver disease in the range above $90 \mathrm{pmol} / \mathrm{min} / \mathrm{mg}$ protein. Only two patients with alcoholic liver disease were found in the range below $90 \mathrm{pmol} / \mathrm{mon} / \mathrm{mg}$ protein, whereas 20 out of 22 normal controls had values below 90 . The highest EOD activity (216.8 $\mathrm{pmol} / \mathrm{min} / \mathrm{mg}$ protein) was measured in an earlier mentioned patient, who was receiving antiepileptic drugs. His EOD value was too high to be included in the Figure.

Table 2 7-ethoxycoumarin 0-deethylation in liver biopsy specimens of patients with varying degrees of alcoholic liver damage

\begin{tabular}{|c|c|c|c|c|c|}
\hline \multirow[t]{2}{*}{$\begin{array}{l}\text { Type of alcoholic } \\
\text { liver damage }\end{array}$} & \multirow[t]{2}{*}{$\begin{array}{l}\text { Age } \\
(y r)\end{array}$} & \multicolumn{2}{|c|}{ Sex } & \multicolumn{2}{|c|}{$\begin{array}{l}\text { 7-ethoxycoumarin 0-deethylase } \\
\text { (pmol/min })^{*}\end{array}$} \\
\hline & & $M$ & $\boldsymbol{F}$ & per mg proten & per $10 \mathrm{mg}$ wet weigh \\
\hline $\begin{array}{l}\text { Fatty liver } \\
\text { Alcoholic hepatitis } \\
\text { Alcoholic cirrhosis without liver failure }\end{array}$ & $\begin{array}{l}42 \pm 9 \\
46 \pm 17 \\
46 \pm 18\end{array}$ & $\begin{array}{l}9 \\
7 \\
2\end{array}$ & $\begin{array}{l}2 \\
0 \\
1\end{array}$ & $\begin{array}{r}121 \cdot 5 \pm 21 \cdot 8 \\
119 \cdot 8 \pm 18 \cdot 9 \\
86 \cdot 5 \pm 31.6\end{array}$ & $\begin{array}{l}82 \cdot 2 \pm 20 \cdot 7 \\
85 \cdot 8 \pm 24 \cdot 3 \\
64 \cdot 4 \pm 34 \cdot 9\end{array}$ \\
\hline
\end{tabular}

*Values represent mean \pm standard deviation of individual determinations in $9000 \mathrm{~g}$ supernatant. The age (mean \pm SD) and the number of male and female patients are given. By using analysis of variance at $P<0.01$ no significant difference between the clinical categories was observed. 
The EOD activity of all alcoholics without liver damage and of four out of six patients with nonalcoholic fatty liver were well below $90 \mathrm{pmol} / \mathrm{min} / \mathrm{mg}$ protein. EOD values higher than 90 were found in two patients with chronic pericholangitis, in one with intrahepatic cholestasis of unknown aetiology, one with hemangioma of the liver, two with nonalcoholic fatty liver, and two with normal livers, as well as in all patients on inducing drugs.

\section{Discussion}

Liver injury caused by alcohol is now the most common cause of liver disease. Since there are instances when either histology or history or both are equivocal, it is important to evaluate in a clinical situation the biochemical impact of ethanol on the liver.

Alcohol causes a wide variety of biochemical and morphological changes in the liver (Lieber, 1973; Hoensch, 1972; Rubin and Lieber, 1968a). Excessive ethanol intake produces a spectrum of pathological findings which range from fatty liver to acute and chronic alcoholic hepatitis and to cirrhosis of the liver (Hoensch, 1972). Fifty-three per cent of our patients with alcoholic liver disease (group II) were found to have fatty liver, $33 \%$ had alcoholic hepatitis, and $14 \%$ had compensated cirrhosis.

Alcohol has been shown to induce the in vitro activity of monooxygenase enzymes in the liver of man and rat (Rubin et al., 1968, 1970; Tobon et al., 1971; Ishii et al., 1973; Liu et al., 1975). Thus it might be possible that induction of monooxygenase activity could serve as an index of the effect of ethanol on the liver in patients who do not take enzyme inducing drugs.

Most studies on drug metabolism of alcoholics have been done in vivo and have demonstrated enhanced rates of drug metabolism (Lieber, 1973). Combined in vivo and in vitro measurements of drug metabolism were performed by Sotaniemi et al. (1977). These authors point out that, in alcoholics, cytochrome P-450 content and antipyrine kinetics are dependent on the mass of parenchymal liver cells.

We investigated the in vitro activity of the monooxygenase enzyme 7-ethoxycoumarin 0-deethylase (EOD) and of NADPH-cytochrome c reductase in liver biopsy specimens of various groups of patients with and without alcoholic liver injury to find out whether the induced state of the enzyme is associated with excessive ethanol intake.

As expected we found that EOD and reductase activity was significantly higher in the liver of patients with alcoholic liver disease (group II) compared with normal controls (Table 1, Fig. 1). Table 2 shows that the enhanced monooxygenase does not vary significantly in the different forms of alcoholic liver injury (fatty liver, alcoholic hepatitis, compensated cirrhosis). EOD was found to be raised even in alcoholic compensated cirrhosis of the liver, although less than in fatty liver and alcoholic hepatitis. These findings are in contradiction to the results of other authors (Schoene et al., 1972; Kratz, 1976), though in decompensated liver cirrhosis with ascites and hypoalbuminia (group IV) we observed a significantly lower activity of EOD, while reductase appeared to be unchanged (Table 1). This is in agreement with the findings of Schoene et al. (1972). As six of eight patients with decompensated liver cirrhosis were alcoholics our results suggest that in combination with alcohol the extent of liver damage affects the monooxygenase but has no influence on the reductase levels.

It was surprising to find normal EOD and reductase values in six alcoholics who showed no signs of liver disease (group V). The amount of alcohol consumed and the duration of the drinking habit were the same in these subjects as in group II. The interval between admission to the hospital and liver biopsy was slightly longer for group V. However, as the inducing effect of alcohol on drug metabolism lasts four weeks at least (Shah et al., 1972) a four-day longer interval could not account for the difference. In addition, there was no evidence that alcoholics without liver disease had discontinued alcohol consumption before admission.

From these results, it was obvious that excessive ethanol consumption does not lead necessarily to an induced state of P-450 dependent monooxygenase enzyme but that raised enzyme activity was related to the alcohol induced liver damage. The fact that higher activities of the enzymes could be demonstrated only in alcoholics with slight to moderate degree of liver damage might be due to the disease process, which could lead to an activation of the microsomal enzyme system (Vesell et al., 1971). Alterations of the endoplasmic reticulum in alcoholic liver disease have been described (Rubin et al., 1970).

The higher EOD activity in five patients who drank no alcohol but were on drugs such as antiepileptics can probably be related to an enzyme induction. This is in accordance with the findings of other authors (Schoene et al., 1975). On the other hand, our findings indicate that therapeutic doses of tranquillisers do not influence EOD activity, not even in the presence of alcoholism.

As the activity of the microsomal monooxygenase was measured in $9000 \mathrm{~g}$ supernatant, the question can be raised whether enzyme determination in the supernatant really represents microsomal enzyme values. This appears to be true as a close correlation $(r=0.77)$ could be shown to exist between values 
obtained simultaneously from supernatant and from microsomal suspension of 16 biopsies (Fig. 2). These specimens came from groups I $(n=4)$, II $(n=3)$, III $(n=1)$, IV $(n=3)$, and V $(n=1)$; the remainder came from various other cases. Furthermore, significantly higher EOD values were obtained from microsomal preparations from three group II patients than from four from group I. These experiments with microsomes support the conclusions drawn from results with supernatant (Fig. 3).

Inflammatory liver changes are not likely to be responsible for enhanced monooxygenase activity, as normal activity was found in chronic active hepatitis, and the transaminases, as well as gammaglutamyl transferases, do not correlate with enzyme activities studied.

The level of significance calculated for wet weight is somewhat lower because of the higher fat content of the liver in alcoholic liver disease (Table 1). Fatty infiltration per se is not related to enhanced monooxygenase activity, as no significant differences in EOD values were observed among group II patients who had fatty liver and those who did not. Moreover, normal activity was observed in patients with fatty liver of presumed non-alcoholic origin and there was no correlation between protein content and monooxygenase values.

We have not evaluated dietary factors which have been implicated in variations of drug-metabolising enzymes (Joly et al., 1975).

Our results obtained from alcoholics with varying degrees of liver damage suggest that enzyme induction does not always follow excessive ethanol intake and that the state of non-induction is associated with normal liver histology.

The enhanced monooxygenase activity in the absence of enzyme inducing drugs might be indicative of alcoholic liver damage.

\section{References}

Hoensch, H. (1972). The effects of alcohol on the liver. Digestion, 6, 114-123.

Hoensch, H., Hartmann, F., Schomerus, H. and Reifferscheid, P. (1977). Monooxygenase activity in liver biopsy specimens of patients with alcoholic liver disease (Abstract). Archives of the Hellenic Medical Societies, suppl. vol. 3, 22.

Hoensch, H., Woo, C. H., Raffin, S. B., and Schmid, R. (1976). Oxidative metabolism of foreign compounds in rat small intestine: cellular localization and dependence on dietary iron. Gastroenterology, 70, 1063-1070.

Ishii, H., Joly, J. G., and Lieber, C. S. (1973). Effect of ethanol on the amount and enzyme activities of hepatic rough and smooth microsomal membranes. Biochimica et Biophysica Acta, 291, 411-420.

Joly, J. G., and Hétu, C. (1975). Effects of chronic ethanol administration in the rat: relative dependency on dietary lipids. 1. Induction of hepatic drug-metabolising enzymes in vitro. Biochemical Pharmacology, 24, 1475-1480.

Kater, R. M. H., Roggin, G., Tobon, F., Zieve, P., and
Iber, F. L. (1976). Increased rate of clearance of drugs from the circulation of alcoholics. American Journal of Medical Sciences, 258, 35-39.

Kratz, F. (1976). Coumarin-7-hydroxylase activity in microsomes from needle biopsies of normal and diseased human liver. European Journal of Clinical Pharmacology, 10, 133-137.

Lieber, C. S. (1973). Hepatic and metabolic effects of alcohol. Gastroenterology, 65, 821-846.

Lieber, C. S., and DeCarli, L. M. (1970). Hepatic microsomal ethanol-oxidizing system. Journal of Biological Chemistry, 245, 2505-2512.

Lowry, O. H., Rosebrough, N. J., Farr, A. L., and Randall, R. J. (1951). Protein measurement with folin phenol reagent. Journal of Biological Chemistry, 193, 265-275.

Liu, S. J., Ramsey, R. K., and Fallon, H. J. (1975). Effects of ethanol on hepatic microsomal drug-metabolising enzymes in the rat. Biochemical Pharmacology, 24, 369-378.

Misra, P. S., Lefèvre, A., Ishii, H., Rubin, E., and Lieber, C. (1971). Increase of ethanol, meprobamate and pentobarbital metabolism after chronic ethanol administration in man and in rats. American Journal of Medicine, 51, 346-351.

Neuvonen, P. J., Penttilä, O. Roos, M., and Tirkkonen, J. (1976). Effect of long-term alcohol consumption on the half life of tetracycline and doxycycline in man. International Journal of Clinical Pharmacology and Biopharmacy, 14, 303-307.

Remmer, H. (1970). The role of the liver in drug metabolism. American Journal of Medicine, 49, 617-629.

Rubin, E., Bacchin, P., Gang, H., and Lieber, C. S. (1970). Induction and inhibition of hepatic microsomal and mitochondrial enzymes by ethanol. Laboratory Investigation, 22, 569-580.

Rubin, E., Hutterer, F., and Lieber, C. S. (1968). Ethanol increases hepatic smooth endoplasmic reticulum and drugmetabolizing enzymes. Science, 159, 1469-1470.

Rubin, E., and Lieber, C. S. (1968a). Hepatic microsomal enzymes in man and rat: induction and inhibition by ethanol. Science, 162, 690-691.

Rubin, E., and Lieber, C. S. (1968b). Alcohol-induced hepatic injury in nonalcoholic volunteers. New England Journal of Medicine, 278, 869-879.

Schoene, B., Fleischmann, R. A., Remmer, H., and von Oldershausen, H. F. (1972). Determination of drug metabolizing enzymes in needle biopsies of human liver. European Journal of Clinical Pharmacology, 4, 65-73.

Schoene, B., Remmer, H., Bolt, H. M., Laar, H. Z., Held, H., and von Oldershausen, H. F., Bolt, M. (1975). Induktion des fremdstoffabbauenden Enzym-Systems beim Menschen in vivo and in vitro unter besonderer Berücksichtigung von Rifampicin. In Aktuelle Probleme der klinischen Hepatologie, pp. 268-289. Edited by A. Neumayer. Witzstock Verlag: Baden-Baden.

Shah, M. N., Clancy, B.A., and Iber, F. L. (1972). Comparison of blood clearance of ethanol and tolbutamide and the activity of hepatic ethanol-oxidizing and drug-metabolizing enzymes in chronic alcoholic subjects. American Journal of Clinical Nutrition, 25, 135-139.

Sotaniemi, E. A., Ahlqvist, J., Pelkonen, R. O., Pirttiaho, H., and Luoma, P. V. (1977). Histological changes in the liver and indices of drug metabolism in alcoholics. European Journal of Clinical Pharmacology, 11, 295-303.

Tobon, F., and Mezey, E. (1971). Effect of ethanol administration on hepatic ethanol and drug-metabolizing enzymes and on rates of ethanol degradation. Journal of Laboratory Clinical Medicine, 77, 110-121.

Ullrich, V., and Weber, P., (1972). The 0-dealkylation of 7-ethoxycoumarin by liver microsomes. Hoppe-Seylers Zeitschrift für Physiologische Chemie, 353, 1171-1177. 
Wattenberg, L. W. (1972). Dietary modification of intestinal and pulmonary aryl hydrocarbon hydroxylase activity. Toxicology and Applied Pharmacology, 23, 741-748.

Williams, C. H., Jr., and Kamin, H. (1962). Microsomal triphosphopyridine nucleotide-cytochrome $\mathrm{c}$ reductase of liver. Journal of Biological Chemistry, 237, 587-595.

Vessell, E. S., Page, J. G., and Passananti, G. T. (1971). Genetic and environmental factors affecting ethanol metabolism in man. Clinical Pharmacology and Therapeutics, 12, 192-201. 